\title{
Editorial: Humour and social media
}

\author{
Eric Weitz \\ Trinity College Dublin \\ weitzer@tcd.ie
}

We are the laughing animal, it has been said, an aspect of humanity that defines us collectively and individually. More importantly, though, we are the animal compelled to cause laughter in others of our species, a mode of interpersonal engagement that serves as the ground-zero principle for humour studies. As technological advances over the past few decades have carved new social contexts from digitally fabricated space, it is not so much a matter of asking "What is new in the way we joke?", but "How have we gone about taking humour with us into the virtual dimension, and how has it necessarily transformed in its various features?".

Humour-wise, the internet stepped through an important portal in the upgrade from Web 1.0 to 2.0, just after the turn of the $21^{\text {st }}$ century. With this transition from static web pages to interactive capabilities, online experience essentially changed performance models: At first we could visit web pages, view videos, and otherwise engage with humour production (among other things) in fourth-wall capacities upon which we exerted no immediate effect. With the technological advances that define the Age of Social Media, online participants could interact with one another in real time, generate content, share, alter, and recombine material. Smartphone culture endowed users with a variety of content-generating capacities, as well as the easily navigable software to edit and re-form that material and then post it in the internet's vast public square.

The mass migration to this other kind of social space makes for some interesting transpositions of the humour transaction, a handful of which are explored in the essays comprising this special issue of the EJHR. Here, then, is a brief consideration of how we have come to renegotiate the terms and conditions for joking in virtual contexts, with particular regard to the fundamentally embodied basis of interpersonal joking and the weave of social fabric within which all this interaction takes place. While our play in the virtual fields of the internet remains untethered by the necessities of material presence, our bodies remain the commissioning agents for all that goes on. We have "a foot in both worlds", as Michael Slevin has said in The Internet and Society (2000: 7) of real and online being, and closer inspection reveals that, as far as humour goes, the principles remain somewhat the same even as we accommodate the pragmatics of a keyboard-driven, geographically sprawling lone togetherness.

As I argue at some length elsewhere (Weitz 2017), several aspects of virtually engaged humour present themselves for inspection from the start. Generally, they have to do with the apparent indispensability of the body-to-body basis for the humour transaction; the default linguistic basis for communication in social media, writing (which is to say, typing) and reading, rather than talking and listening; and the impact of technological practices that 
inform how we can joke virtually. The notion of audience has been redefined in crucial ways, both exponentially more expansive and more privately engaged.

Despite the inability of our bodies to accompany us into the virtual sphere, we seem unable to ignore their insistence on playing parts in the online humour transaction. Most obviously, we find that laughter, the putative raison d'être of the joke and frequent cueing mechanism for joke-telling, refuses to be left out of online joking and banter. Proliferation of so-called e-laughter like haha, abbreviations like lol and lmao, and, of course, emojis, attest to the fact that our bodied responses and joking cues remain an indispensable part of our humour-related communication channels. First of all, we need to make sure the audience knows we are joking (hence the invention of the emoticon ':-)', during the early 1980s); on the other end, we feel driven to close the circuit of joking intent with a lol or a laughing emoji, or alas *groan* or *crickets*. We also know that an attempted joke on a highly charged subject can bring to a chat thread the flaming force of all-caps outrage. Crucially, there is no such thing as 'timing' in online delivery of a joking comment or reply. Intervening comments may appear before one's perfectly composed comic riposte lands on a timeline, thereby interrupting the contextual flow and possibly diverting the mood; and there is no potential for the kind of overlapping synergy that occurs when participants in a pub or at a party pile on contributions in the humour-happy heat of a social moment.

The principles of humour production remain the same in online places, but the technologies we use shape the ways we joke. Puns and hashtaggery make the most of the literary basis for our communication, while the short video and image macro stand to strike quickly and efficiently from the scrolling buffet of a Facebook timeline. Twitter's 140character limit is custom-made for the quick-hit or one-line humour bid. The concepts of humour transaction and audience, although still based on a simple joke told between two people, undergo radical redefinition when any given utterance quickly escapes our wherewithal to control its dissemination. Humour can spread virally through the worldwide group in a digitally driven embodiment of laughter itself, cultivated in evolutionary terms to spread like a contagion through a gathering as quickly and efficiently as possible. Distance, isolation and anonymity - the fact that we are not amongst one another seems to suspend social injunctions against insult and cruelty - all play a part in the potential for offence and distaste.

The essays in this issue of the EJHR focus on specific and potent areas for humour excavation, even as they reveal broader significance regarding internet practices and social valences in and around the online joking transaction. A major feature of the performance constellation for online humour lies in the expandable bands of audience involvement. A humorous utterance made and received in a close-knit context can be retransmitted by various social-media means for widest reception. It thereby may travel across language and culture borders, complicating configurations of in-groups and out-groups and the follow-on joking transactions it spawns. Two of the essays contained herein address the capacity for an online post to collapse geographical distance and for the outward spread of joking interaction well past its target audience. Ibukun Filani's meticulous excavation of Akpos jokes on a dedicated Facebook page focuses on responses to this Nigerian online comic construct, itself rigged with fool- and trickster-like behaviours and expectations. Filani suggests just some of the fertile ground for the analysis of online humour response in all its complexity, including the degrees of humour appreciation denoted by the difference, say, between a 'like' and a 'share'. Importantly, he points to the cognitive delay between a user's immediate response to humour and the choice of how to react via keyboard utterance.

Liisi Laineste and Piret Voolaid analyse the populist spread of humour across borders in the age of the meme and viral sharing, looking in particular at how joke propulsion remains both recognisable and re-fashioned through cross-language, cross-culture travel. They raise 
the related and intriguing issue of so-called jokelore, a term that conflates culture-specific folk associations with humour histories and cross-pollination across time and place.

The examining lens is, in a way, reversed for Liat Steir-Livny's essay on the Hitler Rants YouTube parodies. Although she suggests how this meme can be seen to embody the appropriation of a central, potent comic idea across cultures, she ultimately zeroes in on the highly charged topic of Holocaust-related humour for an Israeli audience. She locates the Hitler Rants memetic phenomenon in the context of culture-wide, post-traumatic reclamation, deconstructing them as parodic, satiric utterances, distinguishing them from other forms of Holocaust humour, and pointing to their currency as contemporary social critique.

Most of us would have no grasp of the design and programming savvy that supports the everyday digital wonders of computer-based, web-related technologies we are able to use without thinking. Indeed, a substantial contribution to our joking capacities derives from the applications we have at our disposal for altering, mixing, and reconstituting found texts and humour-driven templates. Vittorio Marone drills down to the Vine, a prime example of an application that puts technology with an affinity for humour production in practicable reach of anyone with a smartphone. The fact that Twitter announced in October 2016 it would be winding down the application reminds us of the corporate mandate that presides over our online life, often pleased to remain in the background, but all too evident when cases like this arise.

There is no consensus within the humour-studies wing of the academy as to whether humour carries the power to shift hearts and minds against culturally inscribed inequality and the hegemonic structures it serves. Berenice Pahl seeks to make a case through the Russian punk band and political activists, Pussy Riot, who deploy a sort of foolish humour aesthetic against patriarchal and authoritarian conservatisms through an emphasis on shrewdly humorous self-effacement and new-media proliferation. In a far-ranging essay, Pahl weighs into the debate about humour's evaluative valences, whether dispatched from conservative or progressive positions. Her argument for a horizontive humour proposes a model of comic disobedience based on inclusivity, commonality, and a subversive disruption of traditional power lines. Pahl's application of Deleuze \& Guattari's (1987) concept of the rhizome to internet laughter represents an astute theoretical approach to political agency through, as she calls it, a 'bottom-up' perspective.

This handful of essays on humour and social media sends out five invitations to think at length and in depth about this age-old social practice and its relatively new, virtual environment. With Web 2.0 technology still in its teenage years - and Web 3.0 still a tantalising unknown to come - scholarship about humour in this new kind of space is still in its infancy. The importance and prevalence of online humour engagement beckons ever more attention, urging us to look closer at the interface between human being and technological mediation. Hopefully this issue will have provided some impetus for readers and jokers to do just

that. 


\section{References}

Deleuze, Gilles and Felix Guattari (1987). A Thousand Plateaus: Capitalism and Schizophrenia. Brian Massumi, trans. Minneapolis: University of Minnesota.

Slevin, Michael (2000). The Internet and Society. Cambridge: Polity.

Weitz, Eric (2017, in press). 'Online and internet humour', in Attardo, S. (ed.), The Routledge Handbook of Language and Humour. London: Routledge. 